\title{
The Effectiveness Of The Implementation Of The BPJS Health Program In Providing Services To Weak Economic Communities (Study At Helvetia District Health Center, Medan)
}

\author{
Jonathan Maruli Tua Sitompul \\ Department of State Administration Science, University Of North Sumatra, Indonesia.
}

\begin{tabular}{|c|c|}
\hline ARTICLE INFO & ABSTRACT \\
\hline Article history: & \multirow{3}{*}{$\begin{array}{l}\text { The government formed an agency to provide free health services } \\
\text { for the poor through the health insurance program. The application } \\
\text { of the application of the national guarantee is carried out by BPJS } \\
\text { Health. Based on this background the author is interested in writing } \\
\text { this thesis to find out and understand how the effectiveness of the } \\
\text { implementation of the BPJS Health program in providing services to } \\
\text { the economically weak community at the Helvetia District Health } \\
\text { Center, Medan. The method used in this study is a descriptive } \\
\text { method with a qualitative approach. Data collection techniques with } \\
\text { primary data collection in the form of interviews and field } \\
\text { observations, and secondary data collection in the form of } \\
\text { documentation and literature study. Determination of informants in } \\
\text { this study using a purposive technique sampling. From the results of } \\
\text { this research, it was concluded that in accordance with the analysis } \\
\text { tools of the effectiveness indicators, namely, the objectives of } \\
\text { program implementation, the accuracy of the methods and targets of } \\
\text { program implementation, the success of program implementation, } \\
\text { how to obtain resources in implementing the program, adequate } \\
\text { facilities and infrastructure, the state of human resources ( Human } \\
\text { Resources) are adequate, the performance of employees in } \\
\text { providing services has been achieved quite well so that the } \\
\text { implementation of the BPJS Health program at the Helvetia Health } \\
\text { Center in providing services to the economically weak community is } \\
\text { quite effective. However, there are still some obstacles that come } \\
\text { from the community that must be overcome so that services can run } \\
\text { well. }\end{array}$} \\
\hline $\begin{array}{r}\text { Received Nov 02, } 2021 \\
\text { Revised Des 05, } 2021 \\
\text { Accepted Jan 30, } 2022\end{array}$ & \\
\hline $\begin{array}{r}\text { Keywords: } \\
\text { Effectiveness } \\
\text { BPJS Health } \\
\text { Health Services } \\
\text { Economically Weak } \\
\text { Communities } \\
\text { Helvetia Health Center }\end{array}$ & \\
\hline
\end{tabular}

This is an open access article under the CC BY-NC license.

Corresponding Author:
Jonathan Maruli Tua Sitompul,
Department of Business Administration Science,
University Of North Sumatra, Indonesia,
Jl. Dr. Mansur No. 9 Padang Bulan, Kec. Medan Baru, Kota Medan 2022.
Email: marulituasitompul@gmail.com

\section{INTRODUCTION}

Since operating on January 12014 , BPJS Kesehatan has made many efforts to provide services to its participants. However, there are also many complaints from the public about the lack of services in the field, thus requiring attention and improvement in the future. Regarding public satisfaction, perception, and awareness about BPJS Health, two research institutions, namely Myriad Research 
Comitted and PT Sucofindo conducted a survey on September 24- October 15, 2014. Director of Research Myriad Research Comitted Eva Yusuf said, from a total of 17,280 community respondents, as many as $81 \%$ said they were satisfied with BPJS Health. Although the survey results show that most BPJS Health participants are satisfied with the health services provided, there are still participants who are dissatisfied with the services of doctors $(5 \%)$, nurses $(4.7 \%)$, health workers $(4.7 \%)$. ,

These results indicate that the quality of health services for BPJS Health participants is not good when viewed based on the length of the queue for treatment, the narrowness of the waiting room and the length of time participants wait for treatment. Several BPJS Health participants also complained of disappointment related to the complexity of the administrative process to manage BPJS Health requirements, the unfriendly attitude of nurses and doctors, the length of time waiting for medical actions and limited treatment room facilities, and even news of rejection of BPJS Health patients who often heard. Source: (http://sp.beritasatu.com, 2014).

Puskesmas as one of the health care facilities has a very strategic role, especially in an effort to accelerate the improvement of the health status of the Indonesian people. This strategic role was obtained because the Puskesmas is a health facility that is easily accessible by the community. However, public health centers also receive a lot of attention on the performance of health workers. In addition, the community also criticizes various aspects contained in health services, especially nursing services. As recipients of BPJS health services, family members of participants often complain that they are not satisfied with the health services they receive. They assume that patients who are BPJS Health participants receive different services and treatment from other patients in several Puskesmas.

\section{RESEARCH METHOD}

The form used by the author in this research is to use descriptive research methods with a qualitative approach. As it is said that the descriptive method focuses on problems or phenomena that exist at the time the research is carried out or actual problems, then describes the facts about the problem being investigated as they are accompanied by an accurate rational interpretation.

The data analysis technique used in this research is qualitative data analysis, which is to describe and interpret the data obtained in the field from key informants. This analysis is based on the ability of reason to connect facts, data, and information, then the data obtained will be analyzed so that it is hoped that a picture will emerge that can reveal research problems, and then draw conclusions.

\section{RESULTS AND DISCUSSIONS}

From all the data and information that has been collected, both through literature studies, interviews with informants from the Helvetia Health Center as the implementer of the BPJS Health Program and also several communities involved in the program, the data that has been obtained by the author has been arranged systematically in the previous chapter, either through interviews, observations at the research site, secondary and in the form of files and notes obtained by the author in the field as supporting data from this research. Furthermore, the data will be given an analysis of the effectiveness of the implementation of the BPJS Health program in providing services for the economically weak community at the Helvetia Health Center. In carrying out the analysis.

\subsection{The effectiveness of the implementation of the BPJS Health program in providing services for the economically weak community at the Helvetia Health Center, Medan.}

BPJS Health is a legal entity formed to administer a health insurance program and aims to provide health services for all Indonesian people. Health Insurance is a guarantee in the form of health protection so that participants get health care benefits and protection in meeting basic health needs that are given to everyone who has paid contributions or whose contributions are paid by the government. (Law No. 40 of 2004 concerning SJSN). 
Effectiveness means the achievement of goals, targets, objectives by using time according to what was previously planned without compromising quality. Effectiveness is an important concept in an organization because effectiveness provides an overview of the organization's success in achieving its goals. If the results of activities are closer to the target, the higher the effectiveness. weak economic community. The implementation of the BPJS Health program in providing services for economically weak communities is the provision of health services for all Indonesian people participating in BPJS Health which is given to everyone who has paid dues or whose contributions are paid by the government.

To measure the level of effectiveness of the implementation of the BPJS Health program, the authors have formulated indicators that aim to see the level of effectiveness of the implementation of the BPJS Health program carried out by the Helvetia Health Center in providing services for economically weak communities. There are 8 indicators of the effectiveness of the implementation of the BPJS Health program in providing services for the economically weak community, namely:

a. Program implementation objectives.

b. The accuracy of the means and objectives of program implementation.

c. Success of program implementation.

d. How to obtain resources in implementing the program.

e. Adequate facilities and infrastructure.

f. Adequate human resources (Human Resources).

g. Employee performance in providing services.

h. Barriers to program implementation.

\subsection{Program implementation objectives}

The purpose of implementing the BPJS Health program is to organize a health insurance program and provide health services for all Indonesian people. Health Insurance is a guarantee in the form of health protection so that participants receive health care benefits and protection in meeting basic health needs that are given to everyone who has paid dues or whose contributions are paid by the government (Law No. 40 of 2004 concerning SJSN).

\subsection{The accuracy of the program implementation methods and targets}

Based on Law No. 24 of 2011 concerning BPJS, the target of implementing the BPJS Health program is all Indonesian people who pay contributions or their contributions are paid by the government. because in every program implementation there is always an evaluation and supervision carried out related to the implementation of the BPJS Health program through sharing program evaluation meetings. In implementing the BPJS Health program, Helvetia Health Center is also assisted by 2 PUSTU (Sub-Health Health Centers) so as to facilitate the performance of the Puskesmas in providing health services in the right way and on target.

In fact, according to patients seeking treatment at the Puskesmas, they stated that the goals and methods of the Puskesmas in implementing the BPJS program were correct because they immediately felt the benefits of the BPJS Health program so that they felt helped in getting proper health services.

This can be said in the indicators of the accuracy of the method and target of implementing the BPJS Health program in providing services for the economically weak community, which can be categorized as good, the target is correct and the method of implementation is very efficient because it makes it easy for people who want to get health services and this is in accordance with the provisions and government regulations and in its implementation, every health center's performance in providing services at the puskesmas is always monitored and evaluated so that the methods and objectives of program implementation are in line with applicable regulations.

\subsection{The success of the program implementation}

In the implementation of the BPJS Health program, it is hoped that there will be results that can help all Indonesian people get proper health services. Based on Law No. 24 of 2011 concerning BPJS, the expected results from the implementation of the BPJS Health program are:

\footnotetext{
Jonathan Maruli Tua Sitompul, The Effectiveness OF The Implementation Of The BPJS Health Program In Providing Services To Weak Economic Communities (Study At Helvetia District Health Center, 
In line with that, the Helvetia Health Center has also succeeded in running several programs related to the implementation of the BPJS Health program, such as the implementation of the Promotive, Preventive, and Curative programs so that the public is very aware of health. Patients who seek treatment at the Puskesmas also feel the impact of the programs implemented by the Puskesmas and programs from BPJS Health, so that the community is satisfied with the implementation of the BPJS Health program.

From the information above, it can be said that the indicators of the success of the implementation of the BPJS Health program have been said to have been successfully implemented and in accordance with the provisions of the legislation. The community is also satisfied with the results of the services and programs provided by the puskesmas.

\subsection{How to obtain resources in implementing the program}

The success of the organization in obtaining various resources needed to achieve good performance is very necessary. However, in the process of implementing the BPJS Health program at the Helvetia Health Center, the puskesmas does not need to make efforts to obtain the necessary resources in implementing the program because everything has been regulated by the Medan City Government through the Medan City Health Office and the BPJS office.

So in obtaining the necessary resources in implementing health programs, the puskesmas only follow the rules set by the Health Office and the BPJS Health office.

\subsection{Adequate facilities and infrastructure}

Facility resources are all types of equipment, work equipment and facilities that function as the main and/or auxiliary tools in the implementation of work, as well as in the context of interests related to work organizations (Moenir, 1992: 119). If facilities are associated with infrastructure, it can be interpreted as a set of tools that can be used in an activity process, both as a supporting tool and the main tool used to achieve goals.

The facilities and infrastructure owned by the Helvetia health center can be said to be complete and quite good, although there needs to be additions and improvements in the future to improve services to patients. Patients also feel satisfied and comfortable with the existing facilities and infrastructure at the puskesmas when they are treated at the puskesmas.

\subsection{The state of HR (Human Resources) is adequate}

Human resources are one of the most important resources in the continuity of an activity. The higher the quality of human resources, the more the effectiveness, efficiency and productivity of activities will increase (Atmanti, 2005: 31). Therefore, human resources have a fundamental and main role as input managers, processing all resources (inputs) into the resulting output.

The human resources owned by the Helvetia Health Center are adequate in terms of quantity (quantity) where there are 88 employees who assist the Puskesmas in providing good health services for the community. Meanwhile, in terms of quality, the employees already have a fairly good quality, this is evidenced by the statements of patients who claim to be satisfied with the friendly attitude and service provided by the employees so that all patients who seek treatment can be handled properly. However, it is still necessary to improve the quality of employees through training so that the services provided to patients will be better in the future.

\subsection{Employee performance in providing services}

Employee performance is the result of work in quality and quantity achieved by an employee in carrying out his duties in accordance with the responsibilities given to him (Mangkunegara, 2005:9). Employee performance is very influential in knowing the level of effectiveness of a program that is run in the organization.

From the observations made by researchers at the Helvetia health center, it can be seen that the performance of the employees at the Helvetia health center is quite good because the employees work according to their respective expertise and division of tasks. The same thing was also expressed by Mrs. Syamsunihar Hasibuan, SKM, as the Head of the Administrative Subdivision who stated that all employees at the puskesmas already had their respective tupoksi 
and they had a memorandum of duty issued by KAPUS (Head of Puskesmas) so that they worked based on these tupoksi and their respective duties.

In carrying out their performance, puskesmas employees have worked according to established procedures and there is always good communication between employees and employees with superiors so that it has a positive impact in improving the performance of these employees. In addition, each employee's performance is always evaluated through regular meetings, so that employee performance can be monitored very well.

\subsection{Barriers to program implementation}

The stages of implementing a program are the most crucial stages in achieving the success of a program. Through this stage, an overview will be given of what causes the success or failure of a policy and what factors affect the implementation of the program or policy. The factors that influence the implementation of the program can be in the form of supporting or inhibiting factors. We can see this in the implementation of the BPJS Health program at the Helvetia health center in providing services for the economically weak community, where there are obstacles experienced during the implementation of the program.

The biggest obstacle experienced by the Helvetia Health Center in implementing the BPJS Health program and providing services for the economically weak community is that it comes from the patients themselves, namely the patient's impatience in queuing for treatment. In addition, the patient's lack of knowledge regarding the regulations regarding BPJS Health, especially the sanctions received by patients if they forget to complete administrative matters (paying dues) which causes them to not be able to seek treatment using the BPJS Health card.

\section{CONCLUSION}

The effectiveness of the implementation of the BPJS Health program in providing services for economically weak communities at the Helvetia Health Center can be said to be quite effective. This is because the Helvetia Health Center meets the established indicators, namely:

The purpose of implementing the BPJS Health program at the Helvetia Health Center has been implemented and achieved well, where the puskesmas has a goal that is in accordance with the legislation, namely providing health services and covering the health of all people who are registered as BPJS Health participants in the Helvetia sub-district. The accuracy of the method and target of implementing the BPJS Health program in providing services for the economically weak community can be categorized as good at the Helvetia Health Center, the target is correct and the method of implementation is very efficient because it provides convenience for the community, especially the economically weak community who want to get health services and this is in accordance with the provisions and government regulations.

The success of the implementation of the BPJS Health program has been said to have been carried out properly and in accordance with the provisions of the legislation. The community is also satisfied with the results of the services and programs provided by the Helvetia Health Center. In obtaining the resources needed to implement health programs, the puskesmas only follow the rules set by the Health Office and the BPJS Health office. The facilities and infrastructure available at the Helvetia health center really help the performance of the Helvetia health center to achieve the goals of implementing the BPJS Health program in providing services for the economically weak community.

Human resources at the Helvetia Health Center both in terms of quantity and quality are quite good. However, there is still a lot to learn and take part in training so that the quality will be better in the future. All employees at the Helvetia Health Center have worked well in accordance with the main tasks, procedures, and task notes set by the Head of the Puskesmas. They also work and provide the same and equal service to every patient regardless of status or position, so that employees carry out their duties according with the responsibilities assigned to him.

However, it is undeniable that the implementation of the BPJS Health program at the Helvetia Health Center and the provision of services for the economically weak community must have obstacles where the biggest obstacle experienced by the Helvetia Health Center in implementing 
the BPJS Health program and providing services for the economically weak community comes from the patients themselves. , namely the patient's impatience in queuing for treatment. In addition, the patient's lack of knowledge regarding the regulations regarding BPJS Health, especially the sanctions received by patients if they forget to complete administrative matters (paying dues) which causes them to not be able to seek treatment using the BPJS Health card.

\section{REFERENCES}

Ainur Rohman, Ahmad \& dkk. 2010. Reformasi Pelayanan Publik. Malang : Averroes Press.

Akib, Haedar dan Tarigan, Antonius. 2008. Artikulasi Konsep Implementasi Kebijakan: Perspektif, Model Dan Kriteria Pengukurannya, Jurnal Kebijakan Publik.

Azwar, Azrul. Menjaga Mutu Pelayanan Kesehatan. Jakarta: Sinar Harapan. 1996. Atmanti H. D. 2005. Investasi Sumber Daya Manusia Melalui Pendidikan. Jurnal Dinamika Pembangunan. 2 (1) : 30-39.

Bharata, Atep. 2004. Dasar- dasar Pelayanan Prima. Jakarta : Elex Media. Komputindo.

Blum (As'ad, 2000). Pengertian Kepuasan Kerja.

Browne dan Wildavsky. 2004. (dalam Nurdin dan Usman, 2004:70).

Effendy, Onong Uchjana. 1989. KAMUS KOMUNIKASI. Bandung :PT.Mandar Maju.

Gibson, James,L., John M. Ivancevich, dan James H. Donnelly.Jr. 1993. Organizations,Behavior, Structure, and Process. The McGraw Hill Companies Inc. New York.

Jhingan, ML. 1996. Ekonomi Pembangunan dan Perencanaan. Jakarta: PT. Raja Grafindo Persada.

Jones, Charles O. (1996). Pengantar Kebijakan Publik. Ed. 1. Jakarta: PT. Raja Grafindo Persada.

Kotler, Philip. 1994. Marketing management: Analysis, Planing, Implementation, Control. Ed. 8, New jersey: Prentice Hall, Inc.

Kuncoro, Mudrajad. 2006. Ekonomika Pembangunan Teori, Masalah dan Kebijakan. Yogyakarta: UPP STIM YKPN.

Lubis, Hari. S.B. dan Martani Husaini. 1987. Teori Organisasi (Suatu Pendekatan Makro), Pusat Antar Universitas IImu-ilmu Sosial Universitas Indonesia, Jakarta.

Lupiyoadi, Hamdani. 2006. Manajemen Pemasaran Jasa, Edisi Kedua. Jakarta : Penerbit Salemba Empat.

Mahmudi. Manajemen Kinerja Sektor Publik (Mahmudi, 2005:92). Misbach, Lutfie. 2004. Potret Kemiskinan di Jawa Timur.Berkala Ilmiah.

Kependudukan (Scientific Journal of Population), United Nation Population Fund,Vol.6.N0.1.Surabaya : Airlangga Press.

Notoatmodjo, Soekidjo, Pendidikan dan Perilaku Kesehatan, Rineka Cipta, Jakarta, Juni 2003.

Ratminto dan Winarsih Atik Septi.(2005). Manajemen Pelayanan.Yogyakarta: Penerbit Pustaka Pelajar.

Robbins, Stephen. P. 2006. Perilaku Organisasi (alih bahasa Drs. Benjamin Molan), Edisi Bahasa Indonesia, Klaten: PT INTAN SEJATI.

Saryono, Metodologi Penelitian Kualitatif dalam Bidang Kesehatan, Yogyakarta, Nuha Medika, 2010

Singarimbun, Masri.1989. Metode Penelitian Survai. Jakarta : PT.Pustaka LP3LS Indonesia.

Siti Erna Latifi Suryana. 2009. Implementasi Kebijakan tentang Pengujian Sugiono, Metode Penelitian Kuantitatif Kualitatif dan R\&D, Bandung, Alfabeta, 2013.

Susanto, Astrid S. (1975). Pendapat Umum.Bandung:Bina Cipta. Suyanto, Bagong. (2005).Metode Penelitian Sosial: Bergabai Alternatif Pendekatan. Jakarta : Prenada Media.

Tarwaka, dkk. 2004. Ergonomi Untuk Keselamatan, Kesehatan Kerja dan Produktivitas. UNIBA PRESS. Cetakan Pertama. Surakarta. Hal. 35; 97- 101.

Wijaya. (2006)."Pengantar Ilmu Komunikasi”. Pustaka Bangsa Press, Medan.

Undang-undang Dasar Negara Republik Indonesia Pasal 28 ayat (3) Undang-Undang No. 25 Tahun 2009 tentang Pelayanan Publik.

UU No 25 Tahun 2009 Tentang Pelayanan Publik Undang-undang nomor 36 Tahun 2009 tentang Kesehatan

Undang-Undang Nomor 40 Tahun 2004 tentang Sistem Jaminan Sosial Nasional.

Undang-Undang Nomor 24 Tahun 2011 tentang Badan Penyelenggara Jaminan Sosial.

Peraturan Presiden Nomor 12 Tahun 2013 tentang Jaminan Kesehatan.

Surat Edaran Kemenkes Nomor 32 Tentang Pelaksanaan Pelayanan Kesehatan Bagi Peserta BPJS Kesehatan.

Peraturan Badan Penyelenggara Jaminan Sosial Kesehatan Nomor 1 Tahun 2014 Tentang Penyelenggaraan Jaminan Kesehatan. 